International Journal of Literature Studies (IJLS)

ISSN: $2754-2610$

DOI: $10.32996 /$ ijts

Journal Homepage: www.al-kindipublisher.com/index.php/ijlss

\title{
The Argonautic Expedition: The First Worldwide Naval Epic
}

\author{
Angelos Per. Psimopoulos \\ Pharmacist MSc, Researcher and Author, National and Kapodistrial University of Athens, Greece, Riga Feraiou Str 204, 38221 - \\ Volos, Greece
}

$\square$ Corresponding Author: Angelos Per. Psimopoulos, E-mail: angelpsi@otenet.gr

\section{ARTICLE INFORMATION ABSTRACT}

Received: 21 October 2021

Accepted: 13 November 2021

Published: 29 December 2021

DOI: 10.32996/ijts.2021.1.1.13

\section{KEYWORDS}

Aeëtes, Apollonius Rhodius, Argonauts, Colchis, Golden Fleece, Iolcus, Jason, Minyans, Orpheus, Planctae Rocks, silk, Tritonis Lake, wandering rocks.
The Greek mythology is widely acclaimed as one of the richest treasures of universal epics; the myth of the Argonautic Expedition is one of the most interesting Greek myths. Some scientific authorities hold the opinion that the story of the Argonauts was no more than an inspiring fairy-tale, while others insist, it was a real historical event. They believe that it took place in $1225 \mathrm{BC}$, and Colchis was a country located in the Caucasus Mountains, near today's country of Georgia. After a life-long study of more than thirty years using ancient texts and information coming from nautical maps and geography, oceanography and other fields of science, we propose that the real events were quite different from the currently proposed location. The Argonauts, and ancient Greeks at large, wanted to find a sea route to transport silk textiles and new species from the Far East countries to Greece or at least to open the Overland Route leading from the Black Sea to the Far East. In addition, they wanted to transport to Greece silkworm eggs to cultivate silkworms in Greece and produce silk. They started their journey from lolcus and travelled around the Globe; they reached Colchis, Aeëtes' land that was actually China. They took from China eggs of the wild Silkworm instead of the real one and, sailing through the Indian Ocean, reached Suez, where they were forced to pull their ship across the land to reach Tritonis Lake. From there, they exited into the Mediterranean and arrived at lolcus, the city from which they started their journey. That journey was made by the Argonauts around 1510 BC. Presently, giving a plethora of bibliographic references, we shall carefully attempt to expose the real events that happened during those ancient times under the mission code name "transporting the Golden Fleece to Greece". We shall say, who did this perilous feat, when and where it happened, what was the real purpose of the Argonauts' journey, which were the correct routes followed carefully by the Argonauts, what were the countries they crossed or visited and finally what the Argonauts accomplished with that journey.

\section{Introduction}

According to the myth, Phrixus and Helle, children of Athamas, king of Orchomenos, in order to avoid their stepmother, who wanted to kill them, ride upon a "flying ram" and escape to Colchis, Aeëtes' land. ${ }^{2}$. Passing over the Dardanelles, Helle fell off the ram and drowned in the sea. Since then, the Dardanelles changed names and took the name "Hellespont". Finally, Phrixus arrived in Colchis and married Chalciope, Aeëtes' daughter. After Phrixus' death, King Aeëtes killed that ram, took its skin, and after covering it with gold to give it extra value, put it upon an oak tree under the protection of a formidable dragon that breathed flames from its fearful mouth to guard it. Pelias, the regent of lolcus, ordered Jason, his nephew and rightful heir to the throne of lolcus, to sail to Colchis to take and bring back to Greece this Golden Fleece.

Copyright: (c) 2021 the Author(s). This article is an open access article distributed under the terms and conditions of the Creative Commons Attribution (CC-BY) 4.0 license (https://creativecommons.org/licenses/by/4.0/). Published by Al-Kindi Centre for Research and Development, London, United Kingdom.

2 Psimopoulos Ang., 2001. p 237 and 318. 
People believe that Pelias ordered Jason to execute this extremely perilous venture of transporting the Golden Fleece to Greece. ${ }^{3}$ Because he was eager finally to exterminate Jason, the rightful heir to the throne of lolcus, in a devious manner.

In reality, since his childhood, Jason was training for twenty years by Centaur Cheiron and his daughters especially to be able to accomplish this purpose ${ }^{4}$. Therefore, Jason accepted Pelias's order and organized a mission to obtain and transport the Golden Fleece back to Greece. In order to materialize his courageous and superior dreams, he assigned to Argos ${ }^{5} \mathrm{~A}$ famous shipbuilder constructed a ship with 50 oars and sent agents to all cities of Greece, inviting men to come and enlist as the ship's crew. Kings and children of kings from various cities of Greece, about 55 in number, came to the harbour of Iolcus in order to participate in this fascinating mission. ${ }^{6}$. Finally, they choose Jason to undertake the captaincy, naming the ship Argo and the crewmembers Argonauts.

The Argonauts set sail southwards towards the wide exit of the Pagasetic Gulf and, crossing eastward the Aegean Sea, entered via Hellespont and Bosporus the great expanse of the Black Sea reaching Colchis [today Georgia]. Aeëtes, the king of Colchis, in a brilliant appearance, welcomed the Argonauts, who were highly impressed by the wonderful technical works Aeëtes had constructed all over his city.

Eventually, Medea, the daughter of Aeëtes, falls in love with Jason. Aeëtes promised to give to Jason the Golden Fleece if he succeeded in accomplishing a dangerous and highly worthy feat that Aeëtes himself could do easily. ${ }^{7}$. Eventually, with Medea's help, Jason managed to execute the dangerous feat imposed on him by Aeëtes, but Aeëtes refused to give him the Golden Fleece. The Golden Fleece was upon an oak tree, and Medea helped Jason to get hold of it. Immediately after, Jason took Medea upon his boat to become his wife, and all Argonauts departed expediently from Colchis, setting sail backwards to Greece.

Aeëtes chased the Argonauts. To avoid him, they crossed various rivers. According to Orpheus ${ }^{8}$, they travelled to the Atlantic Ocean, according to Apollonius Rhodius ${ }^{9}$, they sailed to the Tyrrhenian Sea and reached the Gulf of Ocean and finally according to Pindar ${ }^{10}$ they passed from the Red Sea [today the Indian Ocean]. In the end, the Argonauts sailing into the Mediterranean Sea arrived in lolcus [today Volos], the city from where they had started their voyage.

Today, based on recent archaeological excavations and geological research, we know that at that remote time, no river existed there through which a boat could sail in a straight route and go from the Black Sea to the Aegean Sea. Everyone who wanted to sail from the Black Sea to the Aegean Sea had to sail through Bosporus and Hellespont.

All this looks strange, and it is not possible to correspond to the facts. Nevertheless, we must keep in mind that the poets who describe the events of Greek mythology always use allegory to describe past memories. Everyone, who wants to find out the real events that are hiding in the epic allegory, has to analyze and demystify those facts.

The sacred centres of ancient Greece did not have the form we believe today [churches, oracles, etc.]. They were centres of gathering information, studying and drawing scientific conclusions. We could say they were something like the Universities today. They aimed at the progress of civilization and the well-being of the people. The wise men of antiquity [Solon, Pythagoras and others] went to study in the sanctuaries of Greece, the Near East, Egypt, Pontus and Italy. They stayed there for many years, taking scholarships from the sacred centres, which were maintained thanks to the contributions of pious people. Usually, in the sanctuary area beside the residential buildings, there was an observatory, a library and a hospital. ${ }^{11}$.

The Sanctuary of Delphi, having information from merchants, realized that individual sailors travelled to faraway countries in the east and brought valuable goods, spices, silk textiles, and other precious products to Greece. Very few sailors knew the way to sail to those countries and the Priests of Delphi decided to reveal this itinerary of the sailors to everyone wishing to travel to those countries and transport goods to Greece.

In addition, the Priests wanted to bring to Greece silkworm seeds that Greeks would cultivate to produce silk. This way, they expected much wealth to flow into the Greek cities, which would affect a multitude of interests. However, it would be almost certain that many people might want to undermine this effort, so they had to keep everything about this attempt secret, and they decided

\footnotetext{
3 Psimopoulos Ang., 2001, p 342-3.

4 a] Doukas N. 1842, Pindar, Pythia 4, 181-5.

b] Psimopoulos Ang., 2001. p 161.

c] Seaton C. R., 1967. Apollonius Rhodius, Argonautica 4, 812-15.

${ }^{5}$ Psimopoulos Ang., 2001. p 347.

${ }^{6}$ Psimopoulos Ang., 2001. p 365-9.

${ }^{7}$ Psimopoulos Ang., 2001. p 532.

${ }^{8}$ Modern Encyclopedic Dictionary "Helios". 1981, Argonautica 1174.

${ }^{9}$ Seaton C. R., 1967, Apollonius Rhodius Argonautica 4, 566-600.

${ }^{10}$ Doukas N., 1842. Pindar Pythia 4, 447-8,

${ }^{11}$ Psimopoulos Ang., 2001, p 155-178.
} 
to use a code name for this mission. The "Golden Fleece" was no more than the coded name of the mission that Greek cities sent to the Far East countries to bring Greece silkworm seeds. To realize that mission, the Argonauts grabbed silkworm cocoons from up of an oak tree without knowing that those were cocoons of the wild silkworm. In the Far East countries, [Japan, China, India and others], this wild silkworm produces a kind of inferior quality silk [wild silk]. Using this silk, people of those countries make textiles by the name "tussore», "tussur", or "tusshah". This name comes from the Indian word "tassar." "Which means the shuttle of the loom. Finally, the Argonauts sailed to China, at that time known in Greece as Colchis, opened the Overland Merchant Route leading from China to the Black Sea, and Georgia became the seaport of the Far East countries to the Black Sea. For this reason, experts believe that Colchis was in Georgia.

To understand the events that took place at that time, at first, we have to see the way in which the Greek myths formed ${ }^{13}$ and find the method through which we can comprehend the real meaning behind them. The epics are poems, and in the poems, the poets describe allegorically whatever they want to put forward. Therefore, in the epics, the historical events as well as the morphology of the land and the physical phenomena change their shape and take an allegorical form. The gods, the demigods, the nymphs and the several other persons of the Greek pantheon, as well as their feats that the Greek mythology describes, are no more than absolute ideas expressed by the poets in an allegorical way. Thus, the story becomes a fairy tale, and its narration is very beautiful.

The name of the god Zeus or Dias derives from the Greek word "zoi", which means life or the word "dia", which means cause, so Zeus or Dias means the one that gives the life. ${ }^{14}$. The name of the god Poseidon comes from the Greek word "posis" [meaning drink, drinking], from which the words "poto = drink", "potiri = glass", "potami = river", and others come from. Poseidon means the water of the sea as well as that of the Ocean, the rivers etc. The name of the goddess Aphrodite comes from the Greek words "a" and "phrena" [=mind, brake], which mean the loss of logic behaviour. The name of the god Ares [Mars] comes from the Greek word "ari" [in Greek " $\left.\alpha \rho \eta \eta^{\prime}\right]$ that means damage ${ }^{15}$. In addition, we have to think that in the lliad or in the Odyssey, the word "lake" means a little Lake or a large one as well as a sea and even an ocean. The word island means a small or a large island and even a whole continent. In Argonautica, the Greek word "potamos", "river" means the sea current. The sea currents are very wide, quite strong, and the water moves at speed, which sometimes exceeds a speed of 7 knots and more. Ships moving by sails and oars cannot proceed opposite of such a sea current.

The Author of the present, after hard work lasting more than 30 years, analyzing the epic allegory and using nautical maps and information from History, Geography, Oceanography, Astronomy, Meteorology and other fields of knowledge, concluded that the events of the Argonautic Expedition are completely different of those people believe today. We can definitely say the Argonauts sailed around the globe and finally they arrived in China, where Colchis and Aea [in Greek Aía] the country of Aeëtes was located.

\section{The Argonauts' journey:}

The information we have about this event mainly comes from the Epic of Orpheus Argonautica. ${ }^{16}$ as well as Apollonius Rhodius Argonautica ${ }^{17}$. In addition, we have some information from Apollodorus Bibliotheca ${ }^{18}$, Pindar ${ }^{19}$ and some excerpts from other authors.

The Argonautic Expedition was a real historical event and took place 30 years before the Trojan War and more than 40 years before the eruption of the Santorini volcano, which destroyed the Minoan Civilization. Minos had sent troops to Troy to take part in the Trojan War, and that happened before the destruction of Crete. The Argonautic Expedition took place around 1510 BC [plus or minus about 20 years $]^{20}$. It is worth noticing that Archaeologists, after excavations in Ithaca, found a tomb that was initially believed it was of Odysseus, but after meticulous research, they found that it dated back to $1400 \mathrm{BC}$ and, therefore, not of Odysseus. In addition, in Orchomenus of Boeotia, Archaeologists found a tomb that, at first, they thought was of Minyas, but after further research, they found that it was between the 17 th to 16 th centuries $B C$, which made it impossible to be of Minyas. ${ }^{21}$. However, according to the chronology indicated here, actually, these tombs belong to Minyas and Odysseus, respectively.

After very careful consideration, the priesthood of Delphi consented to the realization of this mission by the Minyans, [the descendants of Minyas' daughters]. They had to find a sea route so that every merchant could transport the precious spices and silk textiles of the Far East countries to the Mediterranean. In addition, they had to open a Commercial Route over the land that

\footnotetext{
12 Encyclopedia Americana, 1962, 27, 211. Tussore.

${ }^{13}$ Psimopoulos Ang., 2001, p 47-62,

${ }^{14}$ Modern Encyclopedic Dictionary "Helios", 1981, Orpheus Argonautica. The Orphic Hymns.

${ }^{15}$ Buffière Félix, 1962, 1962.

${ }^{16}$ Modern Encyclopedic Dictionary "Helios", 1981, Orpheus Argonautica.

${ }^{17}$ Seaton C. R., 1967.

${ }^{18}$ Papandreou Ap. Bibliotheca.

${ }^{19}$ Doukas N., 1842, Pindar, Pythia 4.

20 Psimopoulos Ang., 2001, p 91.

${ }^{21}$ Psimopoulos Ang., 2001, p 81.
} 
led to the countries in the east. The harbour of this overland route was in the area of Georgia in the Black Sea. The Argonauts' purpose was also to take from China seeds of silkworm to cultivate them in Greece and produce silk. This was the beginning of the first world exploration project by the Minyans [Achaeans - Hellenes, i.e. Greeks] to the end of the world.

In ancient Greece, the sons of the kings, before ascending to the throne they had to perform great feats for the good of the people, and in this way, they would prove their worth as leaders. The mission to bring to Greece the "Golden Fleece" was a PanHellenic attempt, and after Jason's invitation, kings and children of kings of more than 36 Greek cities came to lolcus to join Argo's crew. Noble-men coming from all the cities of Greece, from the far away Thrace in the North to Taenarus [Peloponnese] in the South and from Miletus [Minor Asia] in the east to Ithaca [lonian Sea] in the west, they all arrived in lolcus to enlist to the crew of Argo. In fact, it is worth noticing that at the very last moment, Acastus, the only son of King Pelias, came to join the crew of Argo, which means that the purpose of the mission was something very important and not because Pelias wanted to kill Jason.

lolcus was a city located where today the city of Volos is, and according to a version, the name of Volos comes from the word Iolcus. When everything was ready, the Argonauts put on the boat the supplies [food, water and other things] needed for the trip and departed from lolcus. It is worth mentioning that on the ship, live sheep were loaded to be the food of the crew, the anchors of the ship were of copper ${ }^{22} A$ nd the ship had more than one sails ${ }^{23}$. The ancient writers refer to the sails in the plural, and they use the singular only when they refer to the middle sail and another small one. The Argo used sails to travel, and the Argonauts rowed only in case of need.

Initially, the Argonauts sailed to the Black Sea and tried to find a naval route leading to Colchis. Having explored the area of the Black Sea, Heracles and Polyphemus stayed there to open the over the land Commercial Route leading from the Black Sea to the East Countries. The Argonauts sailed through Bosporus and Hellespont back to the Mediterranean, and passing through Gibraltar; they went out to the Atlantic Ocean. They tried to sail south of Africa and go to the Indian Ocean. Somewhere close to Cape Verde, they could not sail against Benguela Currents, which move too fast. ${ }^{24}$. They turned back to the North and reached the coast of Spain. From there, sailing along the North Atlantic Ocean, they reached the east coast of North America. Then, searching to find a passage to the west, they sailed south along the east coast of North America, passed east of the Bahamas to avoid the Gulf Stream, which moved too fast and reached the NE coast of Hispaniola. [See Map 1].

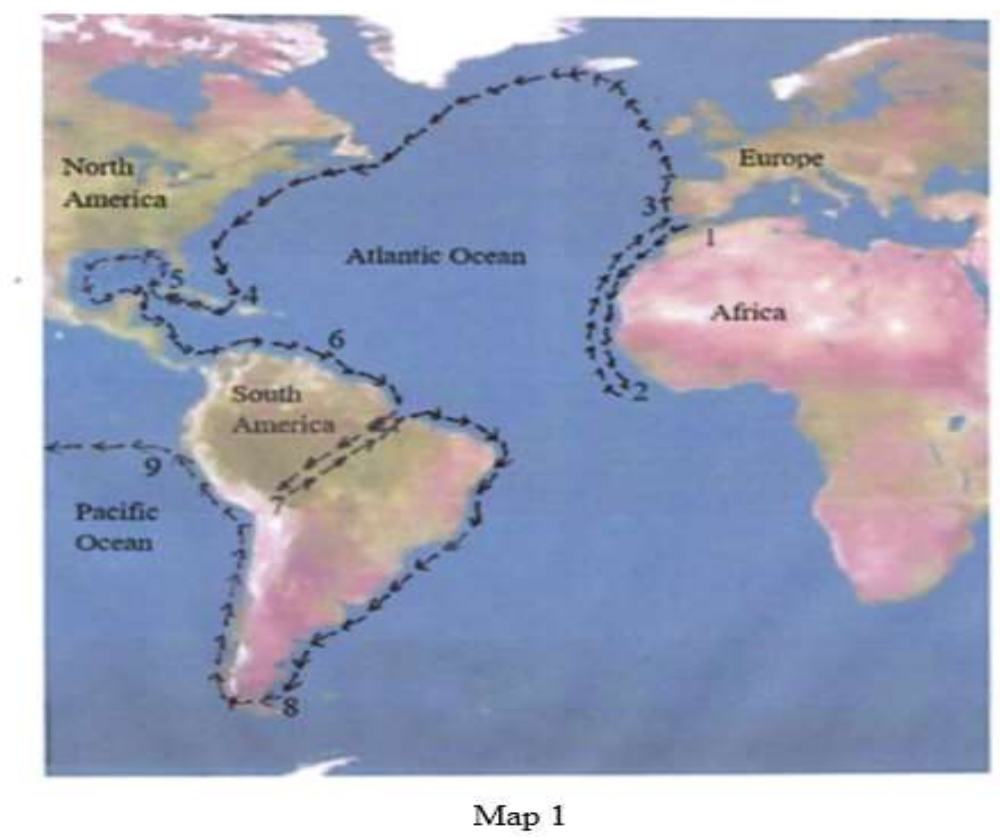

1 Gibraltar, 2 Argo cannot sail southward and turns to the north, 3 Spain, 4 Windward Passage, 5 Melaena Shore, 6 The Island of Trinidad and exit to the Atlantic Ocean, 7 Close to the Springs of Amazon River, 8 The entrance of the Strait of Magellan, 9 Argo turns to the west to go to Asia.

\footnotetext{
22 a] Doukas N., 1842, Pindar, Pythia 4, 42 and 342,

b] Seaton C. R., 1967, Apollonius Rhodius, Argonautica 1, 955-7 and 960,

c] Modern Encyclopedic Dictionary "Helios", 1981, Orpheus Argonautica 499.

${ }^{23}$ Psimopoulos Ang., 2001, p 381.

${ }^{24}$ Psimopoulos Ang., 2001, p 171, 176, 189, 275, 282.
} 
There between Cuba and Hispaniola, the Windward Passage is and in this area, there are plenty of reefs, which by the poetic allegory took the shape of Cyanean Rocks or Clashing Rocks ${ }^{25}$. There, the Caribbean Current is moving from the NE of Hispaniola to the SE of Cuba, and a ship could sail and pass into the Caribbean Sea only when the wind blows to the west and at the flood of the tide, which covers the rocks of the sea.

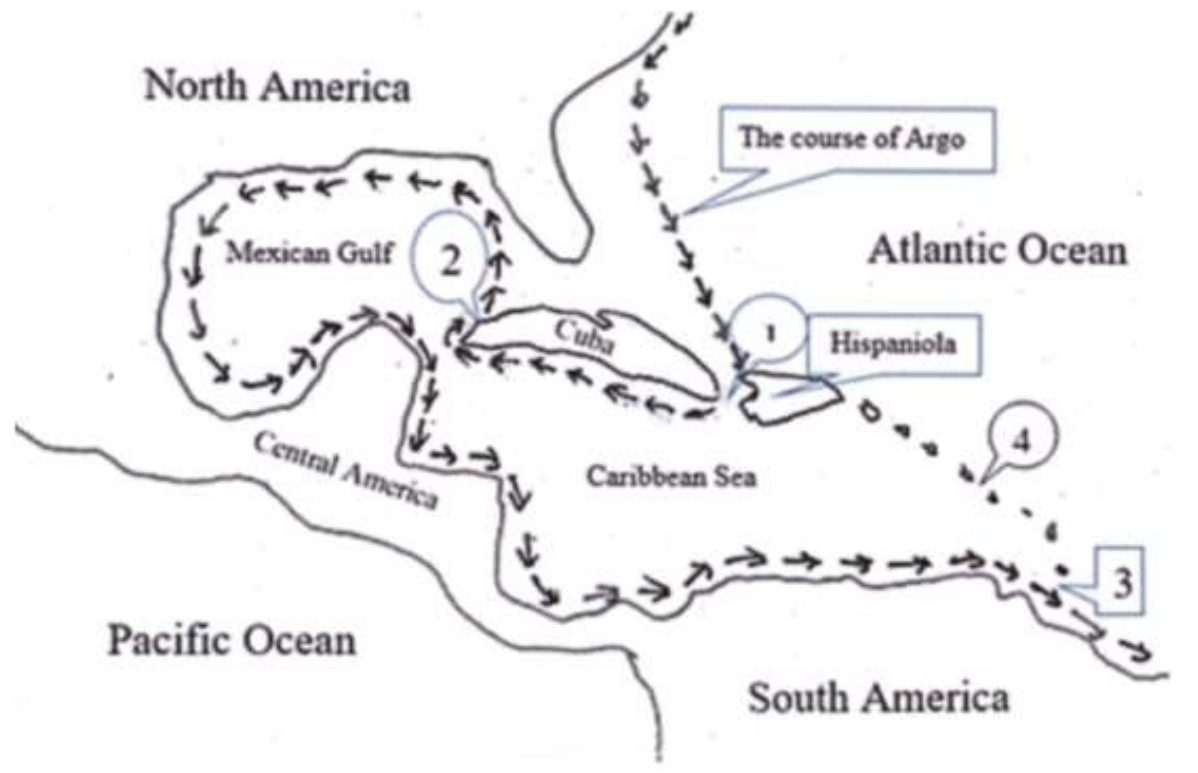

Map 2

The Argonaut's course from the Windward Passage to the Trinidad Island

1 Windward Passage, 2 Melaena Shore, 3 Trinidad Island and exit to the Atlantic Ocean, 4 Caribbean Islands.

The Argonauts stayed close to the Cap-a-Foux of Hispaniola for a while to study the conditions, and at the next period of the high of the tide, they sailed to the west. [See Map 2, point 1]. The waves were high, and Argo doing surfing upon the waves was sailing to the Caribbean Sea. ${ }^{26}$. Argo had to sail more than 40 nautical miles $[75 \mathrm{Km}$ ], and the flood receded before Argo crossed the dangerous area. Therefore, the ship hit on a rock, but fortunately, only small damage was accepted.

The Argonauts sailed along the south coast of the elongate Thyniad or Thynian island of the Argonautica [that is Cuba] and reached the west cape there. It is worth noticing that the Cube, in fact, is an elongated island, which the natives called their island Cubanacán that brings in mind the names Thyniad and Thynian of the Argonautica ${ }^{27}$. In addition, when the Argonauts entered the Caribbean Sea, they stopped seeing the Sea of Bithynia that is the Atlantic Ocean ${ }^{28}$. At the west cape of Cuba, the Argonauts turned north, entered the Mexican Gulf and anchored in Melaena Shore, where today the Archipelagos de los Colorados is. The word "Melaena" in the Greek language means "black", and the name Archipelagos de los Colorados indicates that there the ground has a characteristic color confirming the name "Melaena Shore". At the time the Argonauts arrived there, the sun was going to illuminate the Superboreans. The place of Melaena Shore was $1^{\circ}$ south of the tropic of Cancer, and the sun was close to the tropic of Cancer moving to the North, which indicates the Argonauts arrived there at the beginning of June.

In Melaena Shore, the Argonauts built a temple in honour of goddess Omonoia, [i.e. Concord], and gave oaths of faith to protect each other. Then, they sailed along the coast of North, Central and South America and between Trinidad Island and South America, the Argonauts passed from the Caribbean Sea to the Atlantic Ocean. When the Argonauts exited the Caribbean Sea, they saw

\footnotetext{
25 a] Mertz H., 1964. p 101-111.

b] Psimopoulos Ang., 2001, p 454-458.

26 Psimopoulos Ang., 2001, p 458.

${ }^{27}$ Encyclopedia Americana, 1962, 8, 288a, Cuba 5, History, Discovery and Colonization.

28 a] Psimopoulos Ang., 2001, p 459, 463-4.

b] Seaton C. R., 1967, Apollonius Rhodius Argonautica 2, 619 and 650-2.
} 
again the Sea of Bithynia, the Atlantic Ocean. ${ }^{29}$. There is no such place in the Black Sea that if you go there, you will stop seeing the Black Sea, but later, if you come back from another place, you will see the Black Sea again.

The Gulf of Paria and the estuaries of Orinoco River are close to Trinidad Island. Along the valley of the Orinoco River, the land of king Lycus is. Lycus welcomed the Argonauts and sent his son Dascylus to join the crew of Argo ${ }^{30}$ but there the Argonauts lost two of their comrades. A wild boar killed Idmon, the governor of Argo, and Tiphys died of an illness.

The Argonauts continued their course to the South along the east coast of South America, and soon they reached the Acheron River that is no other than the Amazon River. Especially at the period of rains, the Amazon River close to the Atlantic Ocean is up to $77 \mathrm{Km}$ wide and gives the impression that it is a sea. ${ }^{31}$. Searching to find a passage to the west, the Argonauts entered the Amazon River and sailed up to the confluence of the Marañon and Santiago rivers, where Pongo de Manseriche or Gateway of Parrots is, also known as Gate of Terror. According to Greek mythology, the Gate of Hades has to be there ${ }^{32}$. While they reached at a distance less than $290 \mathrm{Km}$ away from the Pacific Ocean, the Argonauts did not find a passage to the west. They turned back to the Atlantic Ocean and sailed to the South.

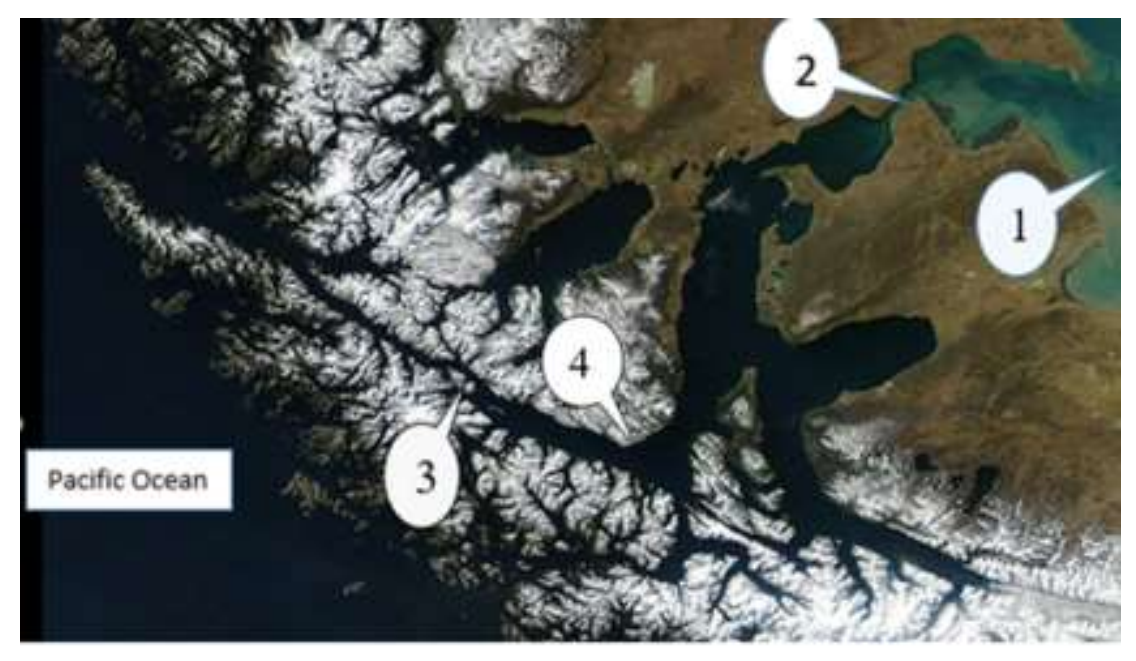

\section{Map 3 \\ The Strait of Magellan \\ 1 The Atlantic Ocean, 2 Primera Angostura, 3 Island Carlos III, 4 Cape Froward}

At Cape of Virgenes, they turned right and entered the Strait of Magellan. At first, they sailed inside Primera Angostura, a narrow passage of no more than $3850 \mathrm{~m}$ wide and about $10 \mathrm{Km}$ long. [See Map 3] In this, narrow passage the current of the tide moves at a speed of up to 6 knots, changing direction about every 6 hours. As Argo was sailing in this canal at a speed of up to 7 knots and relatively to the rocks of the shore, at a time, she had a speed of 13 knots, [7 plus 6] and some hours later only one knot, [7 minus 6]. Therefore, depending on the rocks of the shore, while the ship was running fast forward, one time she appeared moving fast forward but little later the boat appeared as standing at the same position, so the people on the boat saw the rocks of the shore as moving. According to the muse of the poets, the gods named these rocks Planctae Rocks that means wandering rocks. ${ }^{33}$. We have to note that only the name of these rocks was Planctae [Wandering Rocks], which that means in reality, they did not move.

In this area, the wind is quite strong and passing through the crevices of the rocks of the shore causes a lot of noise. The canal is narrow, and the travellers upon a boat can hear this noise easily. Antonio Pigafetta, the historian of Magellan's journey, mentions this noise ${ }^{34}$. According to the poetic allegory, this is the song of the Sirens and woe to him who enchanted by the Sirens' music will approach the shore, immediately he will become debris. According to the poetic allegory, the Argonauts sailing through this

\footnotetext{
29 Psimopoulos Ang., 2001, p 432, 451, 459, 463 and 464.

${ }^{30}$ Seaton C. R., 1967. Apollonius Rhodius, Argonautica 2, 803,

${ }^{31}$ Psimopoulos Ang., 2001, p 502, footnote 92.

32 Psimopoulos Ang., 2001, p 448, 496, 497.

33 Psimopoulos Ang., 2001, p 506.

34 a] Psimopoulos Ang., 2001, p 507-8.

b] Zweig St., Translated by Lampsas G., 1996, p 160.
} 
canal heard the Sirens singing, but Orpheus using his lyre, sang nicer than Sirens, so the Sirens, by their evil, fell off the rocks they were sitting and transformed into rocks.

After Primera Angostura, the Argonauts passed of a square gulf; then, from Segunda Angostura and some miles south at Cape Froward, they turned to the west. [See map 3]. The island of Carlos III is some miles to the west. At this place, there are two narrow passages. Paso Tortuoso is NE of Carlos III and Canal David SW of it. The Argo sailed through Canal David, which is about $1 \mathrm{~km}$ wide. ${ }^{35}$ But Charybdis, a monster, was at the exit of this passage. It was a poetic allegory of a rock upon which the waves hit, causing a loud noise, and it is a very dangerous point for navigation. ${ }^{36}$. However, Argo passed safely, and after some miles, the Argonauts came out to the Pacific Ocean.

In the Pacific Ocean, the Argoanuts sailed north along the west coast of South America and somewhere close to the equator; they turned to the west. [See Map 1, point 9]. They reached the Indonesian Islands [See Map 4] and sailed along the north coast of them. On those islands, the Indonesian Volcano Chain is, and according to the poetic allegory, Chalybes live there, people that spend all their lives digging the ground to find and extract iron for their livelihood. ${ }^{37}$. We should mention here that the Greek word "chalybes" means "people of steel".

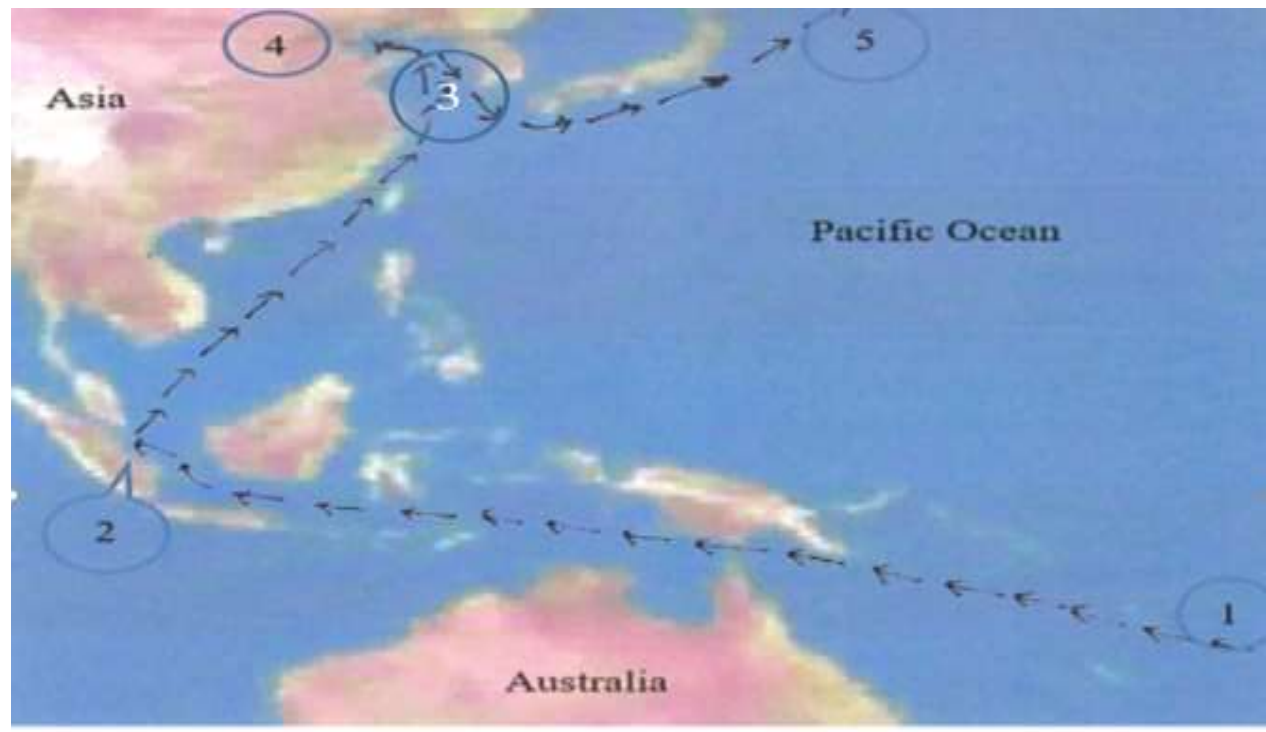

Map 4

The Argonauts course to Aeëtes' land

1 Coming from the South America, 2 The Ares [Mars] Island, 3 The Yellow Sea, 4 Aea, Aeëtes' land, 5 The Argonauts course to North America.

In the area around Sumatra, Borneo and Malaysia always there have been pirates. [see Map 4, point 2]. When the Argonauts arrived there, pirates attacked them. According to the poetic allegory, a vulture of Ares [Mars], a wild bird, attacked them, and a second followed. Then half of the Argonauts put on their armour, took the shields and bows and threw an arrow against the vulture, hit it, and it like a spinning disc fell down in the sea. ${ }^{38}$. Argo was a warship, and the Argonauts were well-trained warriors. The pirates quickly realized that they could not fight against them and fled the area. There in Sumatra, the Argonauts met the children of Phrixus, who were travelling to go to Greece, to the land of their father, but their ship was destroyed by the stormy sea.

The Argonauts took upon their ship the children of Phrixus, who were Aeëtes' grandchildren and sailed north along the east coast of Asia to go to Colchis. They reached the Yellow Sea. [see Map 4, point 3] In Chinese, the word which means sea, as well as the ocean, is "hai". In China, the names almost of all the cities close to the sea end in "-hai", like the well-known Shanghai. The Chinese

\footnotetext{
${ }^{35}$ Psimopoulos Ang. 2001, p 511 and 514,

${ }^{36}$ Modern Encyclopedic Dictionary "Helios", 1981, Orpheus Argonautica 1264.

37 Seaton C. R., 1967. Apollonius Rhodius, Argonautica 2, 1002-8.

${ }^{38}$ Seaton C. R., 1967. Apollonius Rhodius, Argonautica 2, 1033-45.
} 
word "hai" in the Greek language became the diphthong "ai", the country "Aia", [in English Aea], and the king took the name "Aıńtnc", pronounced aeitis- [in English it is Aeëtes] ${ }^{39}$.

The Argonauts sailed into the Yellow River and reached Colchis, [Aea]. [See Map 4]. We see that when the Argonautes arrived in Colchis, Orpheus in his Epic work, uses the name Cyteis [in Greek Kutníc], instead of the name Colchis ${ }^{40}$. Also, Apollonius Rhodius

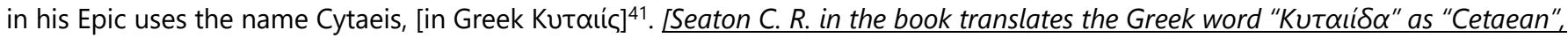

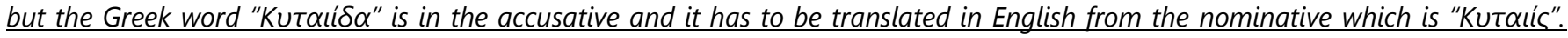
Therefore the translation as "Cytaeis" is more accuratel. In addition, it is known that Liao, during 947-1125 AD, built an autocracy under the name Khitan and ruled territory in Manchuria, Mongolia and NE China. Marco Polo also uses the name Cathay for China. ${ }^{42}$.

When the Argonauts arrived in Colchis, Aeëtes, in a brilliant appearance, welcomed them but later, he blamed his grandchildren because they had brought those noblemen in his country. Perhaps, he thought they would try to take his leadership and become kings in his own country. The older of his grandchildren, Argos replied to his Grandfather and said that the Argonautes were their relatives. They came to transport the Golden Fleece to Greece, and they are willing to pay for it. Also, they are willing to take over the land of Sauromatae and put it under your scepter. ${ }^{43}$. That was an allegory. The land of Sauromatae was west of China, which means that the Argonautes would open the merchant route to the west, so merchants would be able to transport goods to the Black Sea safely.

The Argonauts admired the wonderful technical works Aeëtes had constructed all over his city, and Aeëtes promised to give them the Golden Fleece provided the best one of them would accomplish a feat that Aeëtes himself easily could do. As Aeëtes said, he had two oxen with legs of copper that breathed flames off their mouth. He uses them to plow the ground. However, he did it not to sow wheat or barley but the teeth of a terrible dragon from which men in armor would immediately burst out. He claimed that he would kill those men immediately. He started the feat in the morning and finished the job at dusk. If one of the Argonauts could do this, he would give them the Golden Fleece. That was also an allegory, meaning that Jason had to lead a Caravan safely with Goods to the Black Sea, and if he succeeded in doing this, then surely they safely could transport Goods to the west, and thus they could strike a commercial agreement.

Meanwhile, Medea, the daughter of Aeëtes, fell in love with Jason and undertook to help him in this difficult task. She gave him "a medicine that was commonly known as prometheion", [in Greek it is "Прouń $\theta \varepsilon ı v^{\prime \prime}$-pronounced prométheon-], which made him undefeated ${ }^{44}$. [Seaton C. R., in his book, translates this phrase as "it is called the charm of Prometheus", but this translation is wrong.

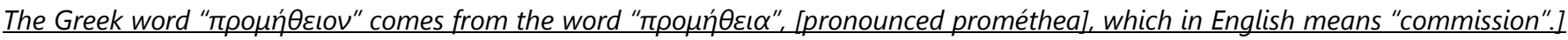
Medea gave money to Jason to pay the people that he would meet in the countries from which the Caravan would pass.

Jason applied upon himself the medicine Medea gave him and became undefeated. He organized a Caravan of Goods and led it to the west. At this place of the Earth, [west of China], nomadic people lived and had no interest in receiving a commission for the Goods to let the merchants pass. They wanted to take the whole amount of the Goods. They were the Indigenous people, mushrooming out from the earth, and Jason had to kill them on the spot.

According to the poetic allegory, after Jason sowed the teeth and Indigenous people leapt out from the ground, he attacked and killed many of them. In addition, he threw "the disc of Ares" among them, so they fought and killed each other and soon they were all dead. This means that Jason caused such animosity between the leaders of the nomadic peoples, which led to their extermination. In that way, Jason soon defeated the Indigenous people, and all Colchians were cheering at Jason's victory. ${ }^{45}$.

Jason succeeded in accomplishing the difficult feat Aeëtes had ordered, and the Caravan reached the Black Sea safely, but Aeëtes refused to give to Jason the Golden Fleece he had promised. The Golden Fleece was upon an oak tree under the protection of a terrible Dragon who was breathing flames off his mouth. The "Dragon" is a national eblem of China, and here it represents China's strict laws, which protected the monopoly of silk and the products made of it. In addition, only Princesses worked in the silk production and made the silk textiles inside the palace. Every Princess knew only a part of the production process. Medea was also unaware of all the stages of the silk production process.

Medea helped Jason again, but she believed that the worms, which produce silk, lived upon oak trees. Therefore, Jason seized the Golden Fleece from an oak tree, which means he took cocoons of the wild silkworm that live upon oak trees. In the countries of

\footnotetext{
${ }^{39}$ Psimopoulos Ang., 2001, p 271-2.

${ }^{40}$ Modern Encyclopedic Dictionary "Helios", 1981, Orpheus Argoanutica 824, 909, 1009.

${ }^{41}$ Seaton C. R., 1967. Apollonius Rhodius, Argonautica 2, 399, 403, 1094, 1267, 3, 228, and 4, 511,

42 Psimopoulos Ang., 2001, p 522

${ }^{43}$ Psimopoulos Ang., 2001, p 529.

${ }^{44}$ Seaton C. R., 1967. Apollonius Rhodius, Argonautica 3, 845.

${ }^{45}$ Seaton C. R., 1967, Apollonius Rhodius, Argonautica 3, 1340-76.
} 
the East, there are some species of incects of the genuses Antheraea and Philosamia, which live upon oak trees and produce wild silk. It is obvious that Aeëtes let the Argonauts take cocoons of the wild silkworms instead of the genuin ones, and in this way, he kept the monopoly of the silk. ${ }^{46}$.

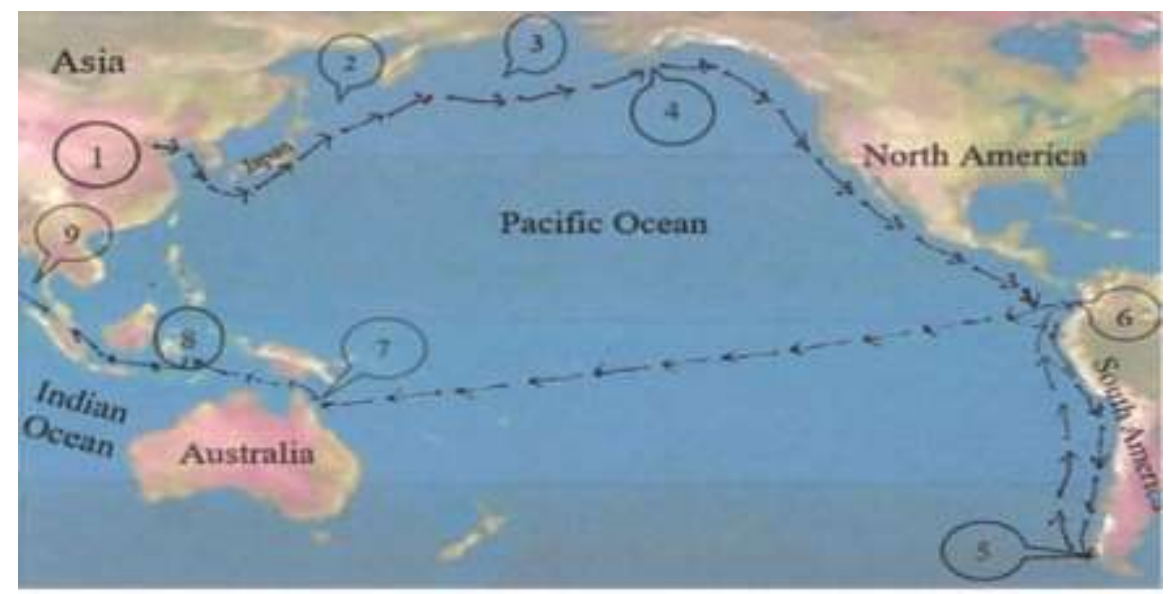

Map 5

The Argonauts' course in the Pacific Ocean

1 Aea, Aeětes* Land, 2 Kuril Islands, 3 The Islands of Aleuts, 4 Aethalia

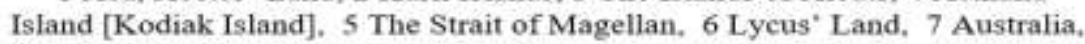
8 Moluccas Islands, 9 The Argonauts' course to the west.

As soon as Jason took the Golden Fleece, he took Medea on the ship to be his wife, as well as Phrixus' children. The Argonauts immediately left Colchis to return to Greece. They sailed to the East, reached the Yellow Sea and sailed east of Japan to the North. [See Map 5]. Aeëtes sent an army to chase them, but this has to be a metaphor. East of Japan, there is Kuro- Shio Current, the fastest sea current of the world, moving to the North, which allegorically took the name of Rhodanus River. The Argonauts sailed Rhodanus River and east of the Kuril Islands; they met the Kuril Current that moves to the South. Where Kuro-Shio Current meets Kuril Current, the waters of the two rivers mixed, and the current turn to the East. The North Pacific Current moves south along the Aleutian Islands and reaches up to Alaska. ${ }^{47}$. It corresponds to the Eridanus River of the Argonautica.

At the time the Argonauts sailed east of Kuril Islands and south of the Aleutian Islands [see Map 5], they were troubled by a horrible smell coming out of this place. Where Eridanus River is, it is a spot Phaethon had fallen off and burnt. In addition, they heard horrible and loud lamentations by the Heliades, the Nymphs, who were crying and mourning him. ${ }^{48}$. That was a poetic allegory. Along with the Kuril Islands and the Aleutian Islands, there is an active volcano in every 25 miles, and the epics refer to this phenomenon. We have to note that according to Greek mythology, Phaethon was the son of the Sun and one day, he took the chariot of his father to lead "helios" [the sun] over the Earth, but he lost control of the chariot, which was going up and down. There was a high risk the sun would burn the Earth, and Zeus killed him to protect the Earth. People believe Phaethon's body fell on the Earth at the place where the Argonauts were passing now.

Reaching Alaska, the Argonauts arrived at Aethalia Island that has to be Kodiak Island. ${ }^{49}$. The name Aethalia comes from the Greek

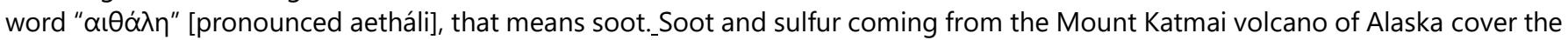
surface of Kodiak Island, and its name Aethalia in Argonautica matches this island.

In addition, another event indicates that the Argonauts sailed to the North Pacific Ocean. North Pacific Current moving to the East close to Alaska divided into three currents. One of them having the name Humboldt or California Current moves south along the west coast of North America, a second one goes among Archipelagos Alexander Islands of Alaska and a third one going North is

\footnotetext{
${ }^{46}$ Psimopoulos Ang., 2001, p 232 and 542.

${ }^{47}$ Psimopoulos Ang., 2001, p 553.

${ }^{48}$ Psimopoulos Ang., 2001. p 552-3.

${ }^{49}$ Psimopoulos Ang., 2001, p 555.
} 
split into seven parts and passes through the straits of the Fox Islands and The Islands of Four Mountains that are really seven ones. ${ }^{50}$.

According to Apollonius Rhodius ${ }^{51}$, close to the place the night has its gates, which means close to the Arctic, Eridanus River is divided into three parts. One of them leads to the coast, a second one to the Ionian Sea and the third one to Sardonian Sea. That one, when it meets a gigantic gulf divided into seven parts and passes through an equal number of straits. Apollonius Rhodius accurately describes the North Pacific currents, and it is worth noticing that the gigantic gulf of Apollonius Rhodius has to be the Bering Sea. ${ }^{52}$.

After Aethalia Island, that is Kodiak Island, searching to find a passage to the Atlantic Ocean, the Argonauts sailed along the west coast of North, Central and South America till they reached close to Magellan's strait. There are many islands in this place, and the Argonauts could not find the entrance of the Strait of Magellan. Argos, Phrixus' child, suggested that Jason sail at another route and thus go more easily to Greece, so the Argonauts turned to the North and sailed up to where Colombia is today. They left Dascylus to return to his fatherland; they turned to the west, crossed the Pacific Ocean and reached Australia. [See map 6].

Crossing the Pacific, there is a day's lap in the calendar. The Argonauts had crossed the Pacific some other times, but now this difference ascertained with certainty and in the Argonautica described as Apsyrtus' murder and cutting him to pieces. Apsyrtus was supposed to be Aeëtes' son, and Aeëtes was the son of the Sun; therefore, Apsyrtus was the grandson of the Sun. At the same time, he considered the same as Phaethon for the Greeks. That is the personification of day. The fragmentation of Apsyrtus allegorically indicates the change of the day in the calendar, and the Argonauts named this place "Cut of the River. "53. At the place where the change of the day takes place; there are many small islands, which has to be the Apsyrtian Islands of Orpheus ${ }^{54}$.

The Argonauts arrived in Australia, and Apollonius Rhodius takes the opportunity and describes the animals of Australia in full detail. ${ }^{55}$. In this country, where now the Argonauts arrived, the animals have confused limbs, and there are no wild beasts as well as animals, which look like humans that are humanoids. In this country, the animals have not undergone the evolutionary process, and they are the same as they were at the beginning of the creation ${ }^{56}$.

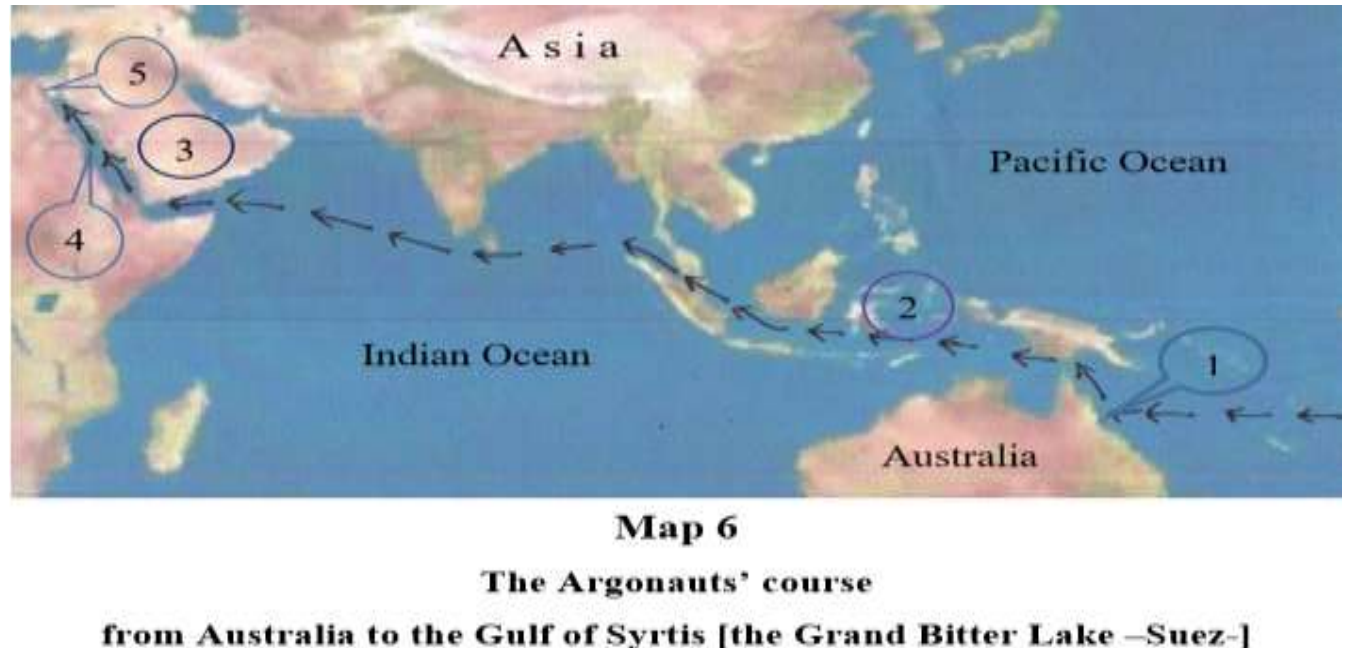

1 Australia, 2 Moluceas Islands, 3 Arabian Peninsula, 4 the Red Sea, 5 the Grand Bitter
Lake [Suez].

In Australia, the kangaroos, these strange animals, live, which give the impression that the parts of their body are confused. In addition, in Australia, there are no wild animals [tigers, lions etc.], and this is the cause that the animals of Australia did not evolve. Also, there are no Humanoids [monkeys, gibbons, chimpanzees and orangutans] in Australia, while in the neighbouring islands, they are a common sight. It is worth mentioning that science today considers that the animals of Australia have not undergone the evolutionary process, which the animals of the other continents have, and this justifies Apollonius Rhodius. He believed that

\footnotetext{
50 Psimopoulos Ang., 2001, p 553-4.

51 Seaton C. R., 1967. Apollonius Rhodius, Argonautica 4, 627-34,

52 Psimopoulos Ang., 2001, p 553-4.

53 a] Seaton C. R., 1967. Apollonius Rhodius, Argonautica 3, 241-46.

b] Papandreou Ap., Apollodorus Bibliotheca 1, 9, 24.

${ }_{54}$ Modern Encyclopedic Dictionary "Helios", 1981, Orpheus Argonautica 1037.

55 Seaton C. R., 1967. Apollonius Rhodius, Argonautica 4, 672-81.

56 Psimopoulos Ang., 2001, p 559.
} 
these adventures of the Argonauts took place in Europe, and yet he describes the animals of Australia, which shows that he was wrong about the place the Argonauts visited.

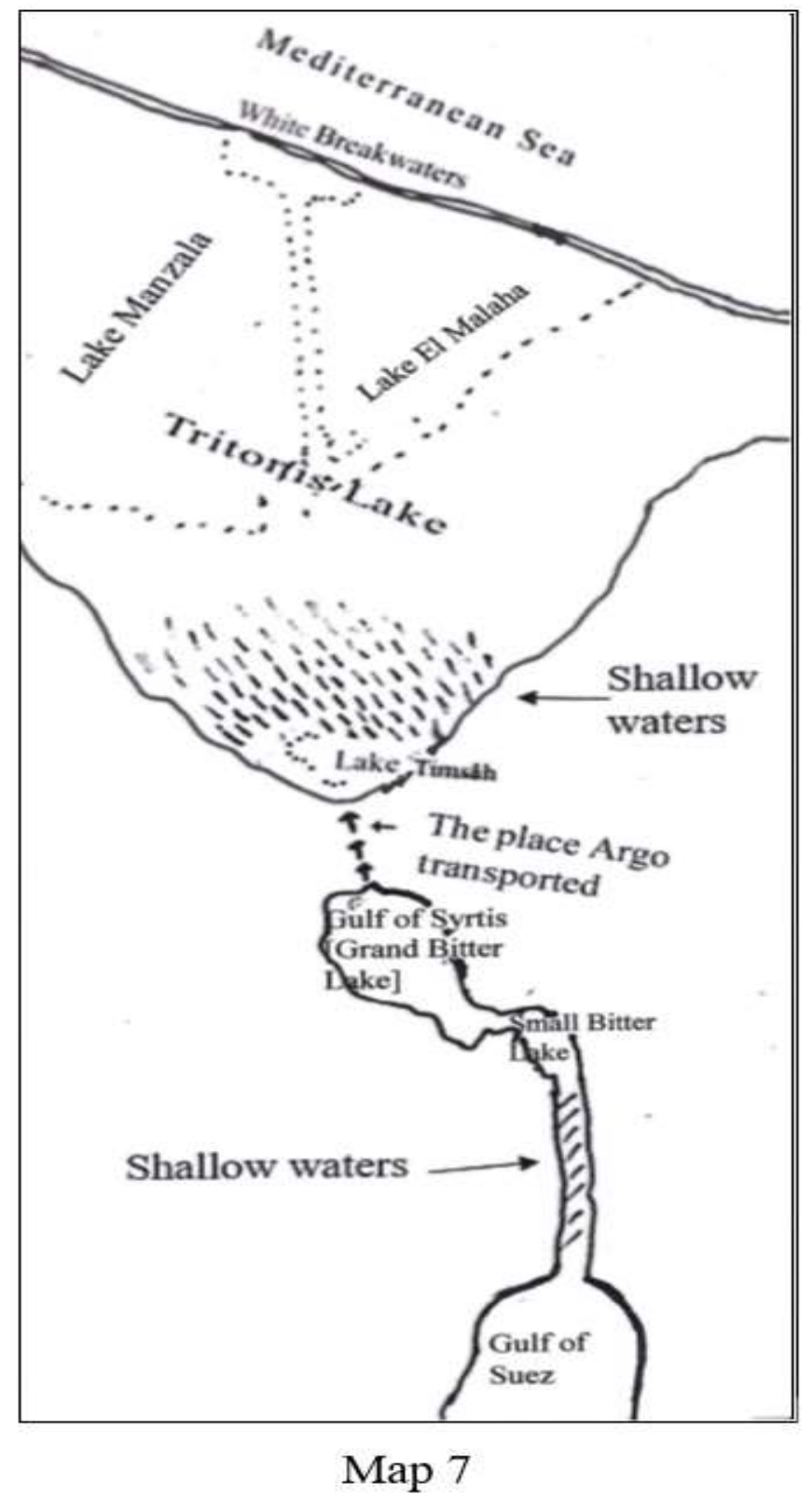

The area of Isthmus of Suez as it was at the time of Argonautic Expedition

From Australia, the Argonauts sailed to Moluccas Islands [the Country of Phaeacians], passed between Sumatra and Malaysia, crossed the Indian Ocean ${ }^{57}$ [the Red Sea of ancient times] and reached the Pelops' land, the Arabian Peninsula. [See Map 6]. The land of Pelops was clearly visible when the Argonauts headed for the Bab-el-Mandeb Strait and entered the Libyan Archipelagos [that is the Red Sea of today $]^{58}$.

In a stormy wind, they needed nine days to cross the Red Sea and to reach deep in the gulf of Syrtis, which today seems to be the Great Bitter Lake in the area of Suez. The morphology of the area of the Isthmus of Suez at this time was somehow different from that today. With time, the area due to sedimentation from the Nile changed in morphology, but then, shallow waters, navigable

${ }^{57}$ Doukas N., 1842, Pindar, Pythia 4, 447-8.

${ }^{58}$ a] Seaton C. R., 1967. Apollonius Rhodius, Argonautica 4, 1231-5.

b] Psimopoulos Ang., 2001, p 571-2. 
only during the period of high tide, would lead from today's Suez to the Bitter Lakes. In the Gulf of Suez, the difference of the sea level by the tide reaches up to $2.3 \mathrm{~m}$, and it is worth noticing that the names Suez and Said are the inverse of the Greek words Zeus and Dias. Egyptians wrote from right to left.

The Argonauts stood for a while on the north coast of the Great Bitter Lake [of today] to study the course of the tide. The tide reached its peak in the morning, and it was then they pulled the ship out of the sea on the land in a distance that the tide could help them. Then, the Argonauts pulled the ship on the land to reach another sea, showing that they knew where they had to go. ${ }^{59}$. After 12 days of great efforts ${ }^{60}$, they covered a distance of twelve and a half kilometres and launched the ship in Tritonis Lake, in a location where Lake Timsâh is today. [See Map 7]. At the time of the Argonauts, there was a very large lake of salt water covering the area from Port Said [of today] to Lake Timsâh [today]. This was the Tritonis Lake of the Argonauts, which was a Lagoon of the Mediterranean.

The Argonauts, in their effort to push the ship upon the land, consumed all the water supplies they had. They saw hallucinations from thirst, as the water of Tritonis Lake was salty. Their only chance to survive was to find drinkable water. ${ }^{61}$. Finally, they found a rock of which some drinking water was running out of a slot, which they highly appreciated ${ }^{62}$.

Experts believe that the Argonauts transported Argo upon the land from Istros River [Danube today] to Eridanus River [today Rhine River]. They say that the Argonauts dismantled the ship and transported it piece by piece to an inaccessible area at a distance of more than 80 kilometres, where they reassembled it. In this case, they would need much more than a hundred days to do all that work. It was impossible to do it in only 12 days. Moreover, all the rivers of Europe and the lakes have drinkable water, and the Rhine River flows into the Atlantic Ocean. On the contrary, to the Argonautica, the water of Tritonis Lake was not drinkable, and from this lake, the Argonauts came out to the Mediterranean Sea.

At the place where Lake Timsâh is today, the water was deep enough to sail the ship, but shallow water was around it, so the Argonauts by the boat were sailing day long, turning around at the same place searching for a passage and only late at the evening they found a passage for the ship to sail. As Apollonius Rhodius says, god Triton helped the ship pass and gave instructions about how they had to sail to reach safety in the Mediterranean. Triton told them that initially there was shallow water that they had to sail at a low speed, but later on, when they meet deep water, they should sail at full speed until they reached the White Breakwaters where they would find an exit to the open sea. From there, they had to sail right off the land. When the land seems to turn to the other place, then, from that cape, they should continue their course in a straight line until they reach Crete and Peloponnese. ${ }^{63}$.

The Argonauts arrived in Tritonis Lake 12 days after they departed from the Gulf of Syrtis. When they departed from Syrtis, the high of the tide was in the morning; now, it was in the evening. In Tritonis Lake, the difference of the sea level by the tide is about one meter, so at the flood of the tide, the Argonauts found an exit to sail north. The Argonauts attributed the increase of the level of the water to the Triton River, which according to the epic allegory, took the form of the god Triton.

Apollonius Rhodius describes in full detail the land of the Isthmus of Suez and assures that the Triton River was no other than the Nile River. As he says, "Triton River was always there with a wide flow, which irrigates the whole country of Hyeria as it never rains in this country. ${ }^{64}$." Aeria or Hyeria was the name of Egypt, and the Nile is the river that irrigates this country.

\footnotetext{
${ }^{59}$ Psimopoulos Ang., 2001, p 579-80.

${ }^{60}$ Seaton C. R., 1967. Apollonius Rhodius Argonautica 4, 1385.-7.

${ }^{61}$ Psimopoulos Ang., 2001, p 590-1.

62 Seaton C. R., 1967. Apollonius Rhodius, Argonautica 4, 1444-8.

${ }^{63}$ Seaton C. R., 1967. Apollonius Rhodius, Argonautica 4, 1573-83.

${ }^{64}$ Seaton C. R., 1967. Apollonius Rhodius, Argonautica 4, 269-71.
} 


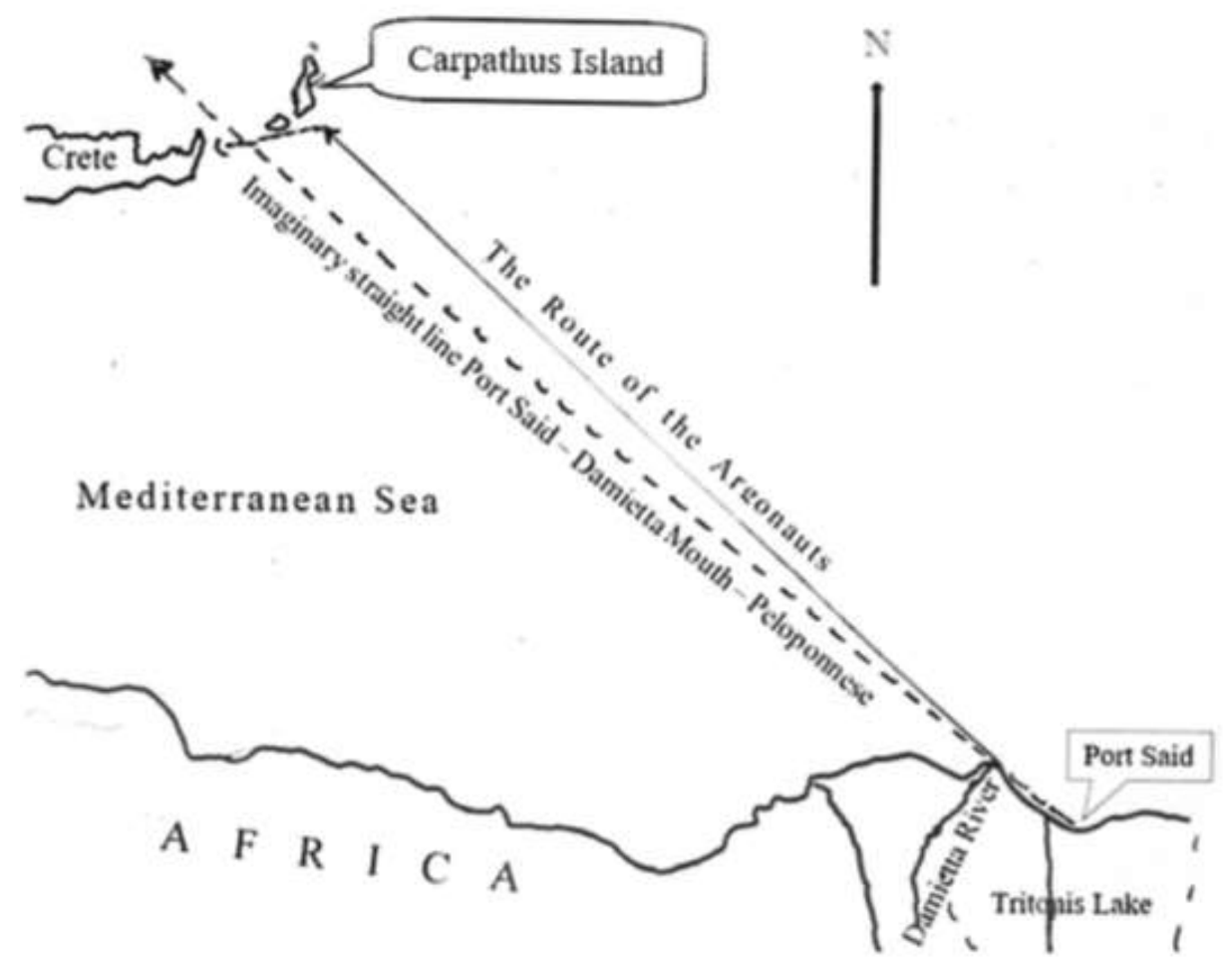

Map 8

The course of Argonauts from Tritonis Lake to Carpathus and Crete

Islands

The Argonauts, before they came out to the Mediterranean, reached White Breakwaters, where Port Said is today. A strip of land is there, which looks like a breakwater. This land today separates the Lakes Manzala and El Malaha from the Mediterranean. The eastern part of Port Said bears the name White Sandy Coast, and Low Sandy Coast is the name in the west part. ${ }^{65}$.

From Port Side, the Argonauts sailed NW along the coast on their left, and when they reached the mouth of the Damietta River, [from this cape], they continued their course in a straight line. [See Map 8]. They travelled for half a day with sails and one and a half day oaring and arrived in Carpathus Island. They had a deviation of about $3^{\circ}$ degrees during their course, which means that the Argonauts consulted a compass. It was impossible to travel two days on the high seas without a fixed point of orientation and travel to their destination with such precision. [In addition, as we shall see later, the Argonauts travelled during a cloudy moonless dark night from Crete to Anaphe, sticking precisely to their orientation.] The Argonauts, in about 48 hours, covered a distance from Port Said to Carpathus of about 302 nautical miles [560 km], which means they travelled at a speed of 6.32 knots.

From Carpathus, the Argonauts headed west and arrived in Crete. There Giant Talos, who was protecting Crete, did not let them an anchor. According to the myth, Talos, going three times a day along the coast of Crete, threw stones at foreign ships and in this way, he protected Crete. This has to be a poetic allegory, meaning that the Cretans had constructed machines that threw stones at foreign ships. In this way, they did not allow them to approach Crete to get supplies. In Crete at that time, Minos was the king, and Pasiphae was his wife. Pasiphae was the sister of Aeëtes and aunt of Medea; therefore, the Cretans allowed the Argonauts to anchor. According to the allegory of the epic, Medea destroyed Talos, Argo anchored in Crete, and the Argonauts supplied themselves with food and water.

Late at night in a cloudy moonless dark night, the Argonauts left Crete, sailed North and before dawn in the light of lightning, they saw Anaphe Island and avoided colliding upon the rocks. Therefore, they named that island "Anaphe", which means "appearing suddenly". In Anaphe, the Argonauts built a temple in honour of the Lightning Apollo, which has to be a lighthouse to help

${ }^{65}$ Psimopoulos Ang., 2001, p 597-8. 
navigation. It is noteworthy that the Argonauts, during their journey, built such temples that are lighthouses and trade centres in many places. ${ }^{66}$.

From Anaphe, the Argonauts headed to Aegina and, sailing between Euboea and Central Greece, arrived in lolcus, the city from which they had begun their journey. In lolcus, Jason made Acastus, son of Pelias, king of lolcus and made it his priority that noblemen should marry Pelias' daughters. ${ }^{67}$.

After the return of Argo, there are many stories about Jason and Medea. Jason certainly dedicated Argo to the temple of Poseidon in Corinth ${ }^{68}$ and settled in Corinth with Medea, his wife. From there, Jason had complete control of the trade, and he was making a lot of money ${ }^{69}$. Very much later and after the death of Acastus, one of their children, Thessalos, took over the kingdom of lolcus, and according to a version, Thessalians took their name after him.

After the Argonautic Expedition, a number of Greek colonies were established in the region of the Black Sea, where all people were welcomed regardless of origin. The Black Sea changed its name and took the name Euxinus Pontus. "Euxinus Pontus is a Latinized

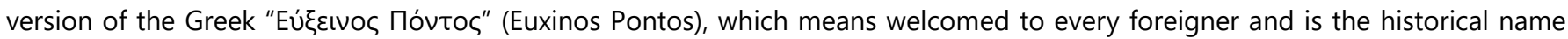
commonly used to describe the body of water we know as the Black Sea." At that time, much wealth accumulated in the Greek cities causing envy and contempt that very soon ended with the terrible Civil War of Troy.

A simultaneous eruption of Mediterranean volcanoes [Cyclops of Odyssey] followed immediately after the Trojan War ${ }^{70}$ brought havoc in the world similar to the Dark Ages, and from then on, the most beautiful fairy tales of Greeks mostly are those related to the Argonauts' campaign.

We should mention here the Argonauts, after their journey, gave orders to Heracles to build an altar for the gods, and he chose Olympia, where he founded the sanctuary with games, to commemorate the events, which later on evolved to the Olympic Games $^{71}$.

In addition, for centuries and until recently, doctors to treat patients used spices coming from the Far East countries, which were very expensive medicines. Therefore, the Argonautic Expedition is a part of the Prehistory of the Science of Pharmacy.

\section{Conclusion}

The Argonauts, after instructions of the Sacred Centers of the time, undertook the mission to find out a sea route to transport expensive spices as well as silk fabrics from the Far East countries to the Mediterranean and to make it known to all sailors. In addition, they had to bring silkworm seeds to Greece to grow and produce silk.

The Argonauts, in order to carry out their mission, sailed around the world and arrived in China [today], where the Colchis of the Ancient Greeks was. They did not succeed in setting up cultivation methods of the silkworm in Greece, but thanks to their voyage, they proved that the only effective way of transporting goods from the East was overland via Georgia and opened the route that led from the Far East countries to the Black Sea. A major seaport of the road leading from Shanghai to the Black Sea was in Georgia at the Caucasus. After the Argonautic Expedition, a number of colonies were established in the Black Sea, which became the World Trade Center.

In the Argonautica, there are allegorical descriptions of phenomena in the Caribbean Sea and in Magellan's strait as well as the volcanos of the Indonesian Islands, Kuril Islands and the Aleutian Islands, the currents of the North Pacific Ocean, the day's lap observed when crossing the Pacific Ocean and the fauna of Australia. Finally, there are descriptions of the transfer of the ship from the Gulf of Suez to Port Said and the strip of sand [White Breakwaters] that separates the Mediterranean Sea from Tritonis Lake. Today this strip of sand separates the Lakes Manzala and El Malaha from the Mediterranean.

About 30 years later, the Trojans closed the Hellespont or demanded expensive tolls for the ships, and the terrible Civil Trojan War broke out. Shortly afterwards, a massive eruption of the Mediterranean volcanoes destroyed all the shores of the Mediterranean and too many ships, resulting in a cessation of trade with countries, which were far away.

Then, a kind of "middle Ages" began until 800 BC. As a result, of the dark ages, a great deal of knowledge was lost, and confusion arose as to the extent and purpose of the Argonaut Campaign. Thus, the "rivers" described in the Argonautic Expedition, which

${ }^{66}$ Psimopoulos Ang., 2001, p 606.

${ }^{67}$ Cactus Philological Group. Volume IV. No 404. 1997. Diodorus Siculus, Library of History 4, 53, 1-2.

${ }^{68}$ Psimopoulos Ang., 2001, p 607

${ }^{69}$ Psimopoulos Ang., 2001, p 610.

70 Psimopoulos Ang., 2001, p 70-75 and 476-8,

71 a] Psimopoulos Ang., 2001, p 172-4.

b] Cactus Philological Group. Volume IV. .Nº. 404, 1997. Diodorus Siculus, Library of History 4, 53, 4-6.

c] Papandreou Ap., Apollodorus Bibliotheca 2, 7, 2. 
are a metaphor for the sea currents, are considered onshore rivers, and researchers placed the Argonauts' course within the rivers of Europe.

It is noted that the water of the sea currents moves much faster than the water of the rivers in their floating part, and it was natural in the epics of the Argonauts with the poetic allegory that the sea currents be called rivers.

During the time of the Argonautic Expedition, very shocking events took place, which was deeply engraved in history. Since then, plenty of cities, mountains and rivers, as well as scientific terms named after heroes or events of that time. Hercules Constellation is named after Heracles [or Hercules], and the constellation Argo Navis of the southern sky is named after Argo, the ship of the Argonauts. The Greek words "lasis" [patient's treatment] and "iama" [a medicine] named after Jason [in Greek láowv -pronounced iason], the Greek word "Cheirurgiki" [that is Surgery] was named after Cheiron or vice versa as well as Asclepieio [a kind of hospital] named after Asclepius.

The herbs of the genus Centaurea, Fam. Compositae, named after Centaurus and herbs of the genus Colchicum, Fam. Liliaceae, named after Colchis. Today experts believe Medea brought in Greece the herb Colchicum automnale from Colchis. Medea was a profound connoisseur of herbal medicines [that is, she was a very clever doctor-pharmacist] of that time. We should not forget

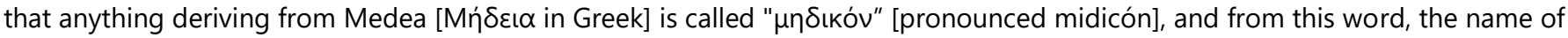
the medical science [of the European languages] comes.

Cite This Article: Angelos Per. Psimopoulos. "The Argonautic Expedition."

\section{References}

[1] Buffière F. (1962). Héraclite Allégories d'Homère. Société d'Edition "Les Belles Lettres". Paris.

[2] Cactus Philological Group. (1997). Diodorus Siculus Apanta. Volume IV. Ancient Greek Secretariat "the Greeks" №. 404. Publications Cactus. Athens.

[3] Doukas N. (1842). Pindar. Typography by Andreas Koromilas. Athens.

[4] Encyclopedia Americana [1962].

[5] Mertz Henriette (1964). The Wine Dark Sea. Chicago.

[6] Modern Encyclopedic Dictionary "Helios". (1981). Edition of the Encyclopedic Inspection "Helios". Athens. Orpheus Argonautica.

[7] Papandreou A. (1973). Apollodorus Bibliotheca. Volumes 2. Publications Tolidis Bros OE. Athens.

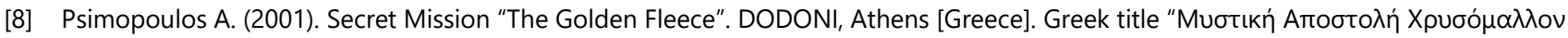
$\triangle \varepsilon \dot{p} \alpha \varsigma^{\prime \prime}$.

[9] Seaton C. R., Apollonius R, A. (1967). William Heinemann Ltd. Harvard University Press.

[10] Zweig S. (1996). Magellan. Translated by Giannis Lampsas. Papyros- Grafikai Technai AE. Athens. 